\title{
Problematika Eksekusi Putusan Harta Bersama di Atas Tanah Adat (Studi di Desa Lebah Sempaga Kecamatan Narmada Kabupaten Lombok Barat)
}

\author{
Baiq Santi Sulistiorini \\ Pengadilan Agama Giri Menang, NTB, Indonesia \\ email: santisasak79@gmail.com
}

\begin{abstract}
This study aims to determine the customary provisions of the Village of Lebah Sempaga regarding the mastery of buildings on customary land, know the legal considerations of the judges and the barriers to execution of shared property on customary land. This research is a field research using normative and sociological juridical approaches and involves judges and litigants, community leaders and traditional leaders of Lebah Sempaga Village. Data mining is done by observation, indepth interviews and documentation studies. The results of this study indicate that the customary provisions of the Lebah Sempaga Village regarding the mastery of buildings on "pauman land" are that the community only has ownership rights to the house building and does not have ownership rights to the land where the house was built. Legal considerations applied by the Panel of Judges of the Giri Menang Religion Court in deciding joint property disputes on customary land include, among others: (a) Consideration of evidence (b) Consideration of factual events (3) Consideration of legal facts. The legal basis used is Article 37 paragraph 1 of Law Number 1 of 1974 in conjunction with Article 97 of the Compilation of Islamic Law and Jurisprudence of the Supreme Court of the Republic of Indonesia Number 58 K / AG / 2015 dated January 27,2015 , that a claim for joint property on customary land can only just sued value. The obstacle in the execution of the object of joint property disputes on customary land is the difficulty to sell the disputed object because no one wants to buy the house because only the house is purchased, not the land because the land is customary land.
\end{abstract}

Keywords: Problems, Execution, Joint Assets, Customary Land.

\begin{tabular}{|c|c|c|}
\hline $\begin{array}{c}\text { First Receive: } \\
\text { 14 August 2019 }\end{array}$ & $\begin{array}{c}\text { Revised: } \\
\text { 28 August 2019 }\end{array}$ & $\begin{array}{c}\text { Accepted: } \\
\text { Pctober 2019 }\end{array}$ \\
\hline $\begin{array}{c}\text { Final Proof Recieved: } \\
\text { 14 November 2019 }\end{array}$ & Published: \\
\hline \multicolumn{3}{|c|}{ Hecember 2019 } \\
$\begin{array}{c}\text { Sulistiorini, B. S., (2019). Problematika Eksekusi Putusan Harta Bersama di Atas } \\
\text { Tanah Adat (Studi di Desa Lebah Sempaga Kecamatan Narmada Kabupaten } \\
\text { Lombok Barat). Schemata, 8 (2), 35-46 }\end{array}$ \\
\hline
\end{tabular}

\section{PENDAHULUAN}

Setiap perkawinan tidak terlepas dari adanya harta benda, harta tersebut bisa jadi didapatkan sebelum melangsungkan perkawinan, harta yang didapatkan ketika perkawinan sedang berlangsung atau pun harta yang didapatkan oleh suami istri selama dalam ikatan perkawinan. Ketentuan tentang harta benda tersebut telah diatur dalam Undang-Undang No. 1 Tahun 1974. Dalam undang-undang tersebut dijelaskasn bahwa harta dalam perkawinan dibagi menjadi dua jenis, yaitu harta bersama dan harta bawaan. Harta bersama adalah harta yang didapatkan selama suami istri tersebut terikat dalam hubungan 
Sulistiorini, B. S., Problematika Eksekusi Putusan Harta Bersama di Atas Tanah Adat

perkawinan dan harta tersebut bukan merupakan harta yang didapatkan melalui warisan, wasiat dan hibah. Pihak suami ataupun pihak istri dapat melakukan sesuatu atau tidak melakukan sesuatu terhadap harta benda tersebut berdasarkan kesepakatan kedua belah pihak. $^{183}$

Secara hukum yang berlaku di Indonesia, berlaku kesatuan bulat antara harta yang diperoleh suami dan harta yang diperoleh istri sejak perkawinan dilangsungkan. Adapun status harta benda yang didapatkan oleh suami atau istri sebelum dilangsungkan perkawinan disebut sebagai harta bawaan. Harta bawaan tersebut menjadi hak suami ataupun istri dan berada di bawah penguasaan masing-masing selama mereka tidak menentukan lain atau tidak membuat perjanjian tertentu terhadap harta bawaan tersebut.

Penyatuan kekayaan melalui konsep harta bersama berlaku selama hubungan perkawinan tersebut masih ada dan tidak boleh diubah atau ditiadakan dengan sebuah perjanjian antara suami dan istri. Apabila ingin melakukan penyimpangan dari ketentuan yang mengatur entang harta bersama sebagaimana tertuan dalam Undang-Undang No. 1 Tahun 1974, maka suam istri harus melakukan perjanjian perkawinan. Disebutkan dalam KHI pada pasal 45 bahwa kedua calon suami istri dapat melakukan perjanjian perkawinan dalam bentuk taklik talak dan perjanjian lain yang tidak bertentangan dengan hukum Islam. ${ }^{184}$

Perjanjian tesebut haruslah dilaksanakan sebelum perkawinan dilangsungkan, dan dibuat dalam bentuk akta autentik di hadapan pejabat yang berwenang, yaitu di hadapan Pegawai Pencatat Nikah (PPN). Ketentuan ini telah diatur dalam KHI pasal 47 ayat 1. Akta autentik tersebut memiliki peranan yang sangat penting, karena akta tersebut dapat dijadikan sebagai alat bukti di persidangan jika terjadi sengketa tentang harta bawaan masing-masing dari pihak suami dan pihak istri.

Jika suatu perkawinan putus karena perceraian dan tidak ada perjanjian perkawinan yang dibuat sebelum melangsungkan perkawinan, maka harta tersebut diatur menurut hukum masing-masing. ${ }^{185}$ Dalam UU No. 1/1974, KHI, KUH Perdata, dan sejalan dengan putusan Mahkamah Agung RI No. 424.K/SIP/1959, yang mengemukakan bahwa apabila perkawinan putus, baik karena perceraian atau karena kematian, maka harta bersama suami

${ }^{183}$ Ahmad Rofiq, Hukum Islam di Indonesia (Jakarta: Raja Grafindo Persada, 1997), 200.

${ }^{184}$ Abdul Manan, Aneka Masalah Hukum Perdata Islam di Indonesia (Jakarta: Kencana, 2008), 104.

${ }^{185}$ Manan, Aneka Masalah Hukum, 105.

Copyright (C) 2019 Schemata Journal

Available online at http://journal.uinmataram.ac.id/index.php/schemata 
dan istri yang diperoleh selama perkawinan berlangsung dibagi dua untuk masing-masing suami dan istri.

Dalam praktik peradilan, hal tersebut tidaklah mudah dan sederhana. Beberapa hal yang terkait dengan aturan tentang harta benda tidak sesuai dengan perkembangan hukum dan kondisi sosial dalam masyarakat yang telah berubah sesuai dengan perkembangan zaman. Perubahan tersebut terlihat dalam berbagai bentuk, baik dalam bidang komunikasi, informasi dan hal-hal yang menyangkut dengan sosial budaya, seperti pihak istri bekerja tidak hanya sebatas menjadi ibu rumah tangga, tetapi juga ikut serta dalam mencari nafkah. Atau sebaliknya, pihak istri bekerja dan mempunyai penghasilan tetap, sementara suami bekerja serabutan dan tidak mempunyai penghasilan tetap. Hal ini tentu akan berpengaruh terhadap pembagian harta bersama apabila terjadi perceraian.

Fenomena yang terjadi di Pengadilan Agama Giri Menang yaitu ada sebuah perkara sengketa harta bersama Nomor: 0287/Pdt.G/2017/PA.GM. Perkara ini merupakan gugatan seorang mantan istri terhadap bangunan rumah yang dibangun ketika ikatan perkawinan mereka masih berlangsung, namun rumah tersebut berdiri di atas tanah yang berstatus sebagai tanah adat. Tanah adat tersebut terletak di Dusun Lebah Sempage Utara, Desa Lebah Sempage, Kecamatan Narmada, Kabupaten Lombok Barat.

Dalam proses persidangan, majelis hakim menghadirkan tokoh masyarakat dan tokoh adat sebagai saksi untuk mengetahui secara jelas tentang status kepemilikan bangunan rumah di atas tanah adat. Selama proses persidangan tersebut tergugat tidak pernah hadir meskipun telah dipanggil secara patut dan sah. Oleh karena itu, majelis hakim mengabulkan gugatan penggugat secara verstek (tanpa kehadiran tergugat). Harta bersama berupa bangunan rumah diputuskan oleh majelis hakim untuk dibagi dua antara penggugat dengan tergugat.

Meskipun majelis hakim telah memenangkan pihak penggugat, putusan tersebut ternyata belum bisa menyelesaikan permasalahan tersebut. Penggugat kesulitan untuk membagi rumah tersebut karena harus dijual terlebih dahulu kemudian membagi hasil penjualannya. Hal ini tentu akan menimbulkan kesulitan bagi penggugat dan tergugat untuk menjual rumah tersebut, karena yang dijual hanya bangunan rumah, sedangkan tanah tempat berdirinya rumah tersebut merupakan tanah adat yang tidak boleh diperjualbelikan. Kondisi seperti ini tentu akan berpengaruh terhadap calon pembeli yang ingin membeli rumah tersebut. Calon pembeli akan berpikir ulang utuk membeli rumah yang tanahnya tidak bisa dimiliki.

\section{Copyright $\odot 2019$ Schemata Journal}

Available online at http://journal.uinmataram.ac.id/index.php/schemata 


\section{Sulistiorini, B. S., Problematika Eksekusi Putusan Harta Bersama di Atas Tanah Adat}

Menurut keterangan Kepala Dusun Lebah Sempaga Utara, tanah yang berada di Lebah Sempaga Utara merupakan tanah adat yang diperuntukkan bagi siapa saja (penduduk Dusun Lebah Sempaga Utara) untuk membangun rumah. Meskipun warga diperbolehkan membangun rumah, akan tetapi mereka tidak mempunyai hak milik terhadap tanah tersebut. Artinya bahwa, tanah tersebut tetap menjadi tanah adat meskipun masyarakat diizinkan untuk membangun rumah. Hal ini tentu akan menimbulkan kesulitan bagi pasangan suami istri untuk membagi harta berupa rumah tersebut jika terjadi perceraian dan menimbulkan kesulitan bagi pengadilan untuk melakukan eksekusi terhadap rumah tersebut.

Berdasarkan fenomena di atas, penulis ingin meneliti lebih jauh bagaimana pertimbangan hukum majelis hakim Pengadilan Agama Giri Menang dalam menyelesaikan sengketa harta bersama di atas tanah adat tersebut. Dalam hal ini penulis akan memfokuskan penelitian pada putusan Pengadilan Agama Giri Menang Nomor 0287/Pdt.G/2017/PA.GM.

Dari latar belakang masalah tersebut diatas, maka penelitian ini merumuskan permasalahan sebagai berikut : 1. Bagaimana ketentuan adat Desa Lebah Sempaga tentang penguasaan bangunan di atas tanah adat? 2. Bagaimana pertimbangan hukum majelis hakim Pengadilan Agama Giri Menang dalam memutuskan gugatan harta bersama di atas tanah adat? 3. Apa hambatan eksekusi harta bersama di atas tanah adat di Desa Lebah Sempaga Kabupaten Lombok Barat?

Bertitik tolak pada rumusan masalah di atas, maka tujuan penelitian ini adalah sebagai berikut : 1 . Mengetahui ketentuan adat Desa Lebah Sempaga tentang penguasaan bangunan di atas tanah adat. 2. Mengetahui pertimbangan hukum majelis hakim Pengadilan Agama Giri Menang dalam memutuskan gugatan harta bersama di atas tanah adat. 3. Mengetahui hambatan eksekusi harta bersama di atas tanah adat di Desa Lebah Sempaga Kabupaten Lombok Barat.

Adapun manfaat penelitian ini diharapkan berdaya guna secara teoritis hasil penelitian ini 1. Diharapkan menjadi sumbangan pemikiran bagi perkembangan hukum Islam khususnya bidang hukum keluarga, sehingga akan lebih membantu dalam menyelesaikan masalah-masalah perkawinan khususnya mengenai harta bersama. 2. Hasil penelitian ini diharapkan dapat menjadi bahan masukan bagi pengembangan ilmu pengetahuan di bidang hukum Islam khususnya hukum keluarga mengenai harta bersama. Dan secara praktis; 1. Bagi akademisi; untuk menambah kajian keilmuan dalam bidang

\section{Copyright () 2019 Schemata Journal}

Available online at http://journal.uinmataram.ac.id/index.php/schemata 
hukum perkawinan khususnya mengenai harta bersama. Penelitian ini dapat dijadikan sebagai bahan rujukan untuk penelitian-penelitian selanjutnya. 2. Bagi elit pengambil kebijakan; untuk mengembangkan pemikiran dan mewujudkan kepastian hukum bagi pejabat di pengadilan agama mengenai peraturan-peraturan tentang perkawinan, khususnya mengenai harta bersama. 3. Bagi masyarakat pada umumnya; untuk memberikan wawasan keilmuan dalam bidang hukum keluarga beserta peraturan-peraturan yang berkaitan dengannya.

\section{METODE PENELITIAN}

Penelitian ini termasuk penelitian lapangan (field research) dan penelitian kepustakaan. Penelitian ini termasuk dalam jenis penelitian hukum, karena penelitian ini diarahkan untuk mengetahui pertimbangan hukum yang diterapkan oleh majelis hakim Pengadilan Agama Giri Menang dalam memeriksa dan mengambil keputusan terhadap perkara sengketa harta bersama berupa bangunan rumah yang berdiri di atas tanah adat.

Pendekatan yang digunakan dalam penelitian ini adalah pendekatan yuridis normatif dan yuridis sosiologis. Yuridis normatif merupakan suatu pendekatan masalah yang berusaha mengakaji dan menelaah perundang-undangan sebagai landasan untuk menemukan jawaban terhadap permasalahan yang diteliti. ${ }^{186}$

Penelitian ini dispesifikasikan sebagai penelitian deskripsi, yang analisis datanya bersifat deskriptif analitis. Deskripsi maksudnya, pada umumnya penelitian ini bertujuan mendeskripsikan secara akurat, faktual dan sistematis mengenai permasalahan yang dikaji, yaitu mengenai penyelesaian sengketa harta bersama di atas tanah adat di Pengadilan Agama Giri Menang. ${ }^{187}$ Penelitian ini dilaksanakan di Desa Lebah Sempaga Kecamatan Narmada Kabupaten Lombok Barat. Untuk mendukung perolehan data yang akurat, penelitian ini juga dilakukan di Pengadilan Agama Giri Menang yang menangani perkara gugatan harta bersama di atas tanah adat.

Adapun jenis-jenis data yang diperlukan dalam penelitian ini sebagai berikut: 1). Data Primer, merupakan data yang didapatkan oleh peneliti secara langsung dalam melakukan penelitian di lapangan. ${ }^{188}$ Data primer dalam penelitian ini berupa salinan

${ }^{186}$ Cholid Narbuko dan H. Abu Ahmad, Metodologi Penelitian (Jakarta: Bumi Angkasa, 2002), 23.

${ }^{187}$ Bambang Sunggono, Metodologi Penelitian Hukum (Jakarta: PT. Raja Grafindo Persada, 1998), 36.

${ }^{188}$ Zainudin Ali, Metode Penelitian Hukum (Jakarta: Sinar Grafika, cet. ke-5, 2014), 106. 
Sulistiorini, B. S., Problematika Eksekusi Putusan Harta Bersama di Atas Tanah Adat

putusan Pengadilan Agama Giri Menang Nomor 0287/Pdt.G/2017/PA.GM dan pernyataan lisan dari penggugat dan tergugat, Majelis Hakim Pengadilan Agama Giri Menang, masyarakat serta tokoh adat Desa Lebah Sempaga Kecamatan Narmada Kabupaten Lombok Barat. 2). Data Sekunder, adalah data yang diperoleh melalui penelitian kepustakaan, penelitian kepustakaan adalah teknik untuk mencari bahan-bahan atau datadata yang bersifat sekunder yang ada hubungannya dengan data primer.

Untuk memudahkan peneliti dalam memperoleh dan menganalisa data, maka diperlukan teknik pengumpulan data yang tepat. Teknik pengumpulan data yang digunakan adalah sebagai berikut:

a. Observasi

Observasi adalah melakukan pengamatan dan pencatatan terhadap permasalahan yang diteliti secara langsung di lokasi penelitian. Adapun data yang diperoleh dalam observasi tersebut adalah informasi umum tentang tanah adat di Desa Lebah Sempaga Kecamatan Narmada Kabupaten Lombok Barat.

b. Wawancara

Wawancara (interview) adalah suatu bentuk komunikasi atau percakapan yang bertujuan untuk mendapatkan informasi dengan cara tanya jawab secara lisan antara dua orang atau lebih dengan saling melihat dan mendengar secara langsung pertanyaan serta jawaban. Adapun informan dalam penelitian ini adalah majelis hakim yang menangani perkara gugatan harta bersama No. 0287/Pdt.G/2017/PA.GM, pihak yang bersengketa dan tokoh adat Desa Lebah Sempaga. Sedangkan data yang akan diperoleh melalui wawancara ini adalah data terkait ketentuan adat Desa Lebah Sempaga tentang penguasaan bangunan di atas tanah adat dan hambatan-hambatan dalam membagi bangunan rumah bagi pasangan suami istri yang telah bercerai.

c. Dokumentasi

Dokumentasi merupakan metode untuk memperoleh data dengan cara mengumpulkan dan memilih berkas-berkas tertulis ${ }^{189}$, seperti buku-buku yang membahas tentang harta bersama dan arsip-arsip lain seperti putusan pengadilan terkait sengketa harta bersama di atas tanah adat. Metode ini diterapkan untuk mengumpulkan data tertulis yang memberikan keterangan sesuai dengan data yang dibutuhkan, yaitu data mengenai lokasi

${ }^{189}$ Sugiono, Metode Penelitian Kuantitatif Kualitatif dan R\&D (Bandung: Alfabeta, cetakan ke-22, 2015), 240. 
penelitian, konsep-konsep yang membahas tentang harta bersama, baik berupa buku-buku, kitab-kitab, jurnal, artikel dan sebagainya.

Model analisa data yang digunakan adalah Model Miles and Huberman yang mengemukakan bahwa aktivitas dalam analisis data kualitatif dilakukan secara interaktif dan berlangsung secara terus menerus sampai tuntas ${ }^{190}$. Adapun tahapan dalam analisa ini adalah a) Reduksi Data yakni proses merangkum, memilih hal-hal yang pokok, memfokuskan pada hal-hal yang penting, mencari tema dan pola untuk memberikan gambaran yang lebih jelas tentang pokok masalah yang diteliti. b) Penyajian Data, proses memudahkan dalam memahami apa yang terjadi, maka data dapat terorganisasikan, tersusun dalam pola hubungan. c) Penarikan Kesimpulan dan Verifikasi.

Adapun kerangka berfikir yang digunakan adalah logika penalaran induktif berdasarkan data yang diperoleh digunakan untuk menyusun dan menjelaskan konsep baik dalam teks al-Qur'an maupun hadis dan Undang-Undang Perkawinan yang dijadikan acuan untuk melihat validitas pertimbangan hukum yang diterapkan oleh Majelis Hakim Pengadilan Agama Giri Menang dalam memberikan putusan terhadap perkara gugatan harta bersama. Tujuan utama dari analisa kualitatif adalah mendiskripsikan apa yang berlaku saat ini. Di dalamnya mendeskripsikan, mencatat, menganalisis dan menginterprestasikan kondisi yang sekarang terjadi. Guna memperoleh informasi yang sesuai dengan fokus penelitian yang peneliti analisis. Penelitian ini tidak menggunakan hipotesa, tetapi hanya mendeskripsikan informasi data yang sesuai dengan variabel-variabel yang diteliti.

\section{HASIL DAN PEMBAHASAN}

Berdasarkan hasil wawancara penulis dengan tokoh masyarakat dan tokoh adat di Desa Lebah Sempaga, "tanah pauman" merupakan tanah hasil membuka hutan oleh masyarakat yang pertama kali menempati wilayah tersebut. Kemudian "tanah pauman" dimanfaatkan secara turun-temurun oleh generasi setelah mereka yang ada di Dusun Lebah Sempaga. Berdasarkan hukum pertanahan, "tanah pauman” tidak memiliki legalitas karena belum mempunyai sertifikat. Walaupun demikian, masyarakat yang menempati "tanah pauman" tetap dibebankan untuk mengeluarkan uang setiap tahun untuk membayar pajak bumi dan bangunan.

${ }^{190}$ Sugiono, Metode Penelitian Kuantitatif, Kualitatif dan R\&D, (Bandung: Alfabeta, 2015), 
Masyarakat Dusun Lebah Sempaga yang menempati dan mendirikan bangunan rumah di "tanah pauman" mempunyai hak penuh atas kepemilikan bangunan rumah tersebut. Akan tetapi, mereka hanya mempunyai hak milik atas bangunan rumah saja, sedangkan tanah tempat mendirikan rumah tersebut tetap menjadi milik adat (kelompok). Berdasarkan aturan adat, warga tidak diperbolehkan untuk menjual tanah yang ditempati karena tanah tersebut bukan milik pribadi.

Untuk membahas permasalahan status kepemilikan bangunan yang dibangun di atas "tanah pauman", penulis terlebih dahulu membahas aturan tentang kepemilikan tanah kosong yang dibuka dan dikelola oleh sekelompok masyarakat. Setelah itu, penulis akan membahas tentang status kepemilikan bangunan di atas tanah adat tersebut.

\section{Pengaturan Kepemilikan Hak Atas Tanah Bagi Yang Membuka Tanah Kosong Menurut UUPA dan Hukum Islam}

a. Kepemilikan Hak Atas Tanah Kosong Menurut UUPA

Menurut Pasal 21 ayat 1 Undang-Undang Pokok Agraria No. 5 Tahun 1960, bahwa: "Hanya warga negara Indonesia dapat mempunyai hak milik". Dalam pasal 9 ayat 2, bahwa : "Tiap-tiap warganegara Indonesia baik laki-laki maupun wanita mempunyai kesempatan yang sama untuk memperoleh sesuatu hak atas tanah serta untuk mendapat manfaat dan hasilnya, baik bagi diri sendiri maupun keluarganya". Dalam pada itu perlu diadakan perlindungan bagi golongan warganegara yang lemah terhadap sesama warganegara yang kuat kedudukan ekonominya.

Untuk mendapatkan hak milik atas tanah kosong, orang tersebut harus beritikad baik terhadap tanah kosong. Maksudnya adalah dengan cara pembukaan tanah atau menjaga kelestarian tanah kosong tersebut dengan cara menjadikan tanah kosong yang sebelumnya mati menjadi produktif. Selain orang dengan kewarganegaraan Indonesia, ada badan hukum yang dapat menggarap atau membuka tanah kosong tersebut, dan ini sesuai dengan ketentuan Pasal 10 Undang-Undang Pokok Agraria No. 5 Tahun 1960, bahwa: "Setiap orang dan badan hukum yang mempunyai sesuatu hak atas tanah pertanian pada azasnya diwajibkan mengerjakan atau mengusahakannya sendiri secara aktif, dengan mencegah cara-cara pemerasan".

Ketentuan cara terjadinya hak milik dengan pembukaan tanah di atur dalam Pasal 22 UUPA No. 5 Tahun 1960 berlaku menurut hukum adat, bahwa: “Terjadinya hak milik menurut hukum adat diatur dengan Peraturan Pemerintah". Ketentuan ini berlaku menurut hukum adat, dimana hukum adat menggunakan cara penggunaan tanah guna pengakuan

\section{Copyright $\odot 2019$ Schemata Journal}

Available online at http://journal.uinmataram.ac.id/index.php/schemata 


\section{Sulistiorini, B. S., Problematika Eksekusi Putusan Harta Bersama di Atas Tanah Adat}

dan terjadinya hak milik. Cara ini diatur dalam masyarakat adat supaya tidak terjadi hal-hal yang merugikan kepentingan umum dan negara. ${ }^{191}$

Hak milik atas tanah, harus didaftarkan ke Kantor Pertanahan Kabupaten/Kota setempat. Pendaftaran ini merupakan alat pembuktian yang kuat berdasarkan pasal 23 UUPA. Pendaftaran tanah untuk pertama kalinya atas Hak Millik diterbitkan tanda bukti hak berupa sertifikat. Sertifikat menurut pasal 1 angka 20 PP No.24 Tahun 1997 tentang Pendaftaran Tanah, adalah surat tanda bukti hak sebagaimana dimaksud dalam pasal 19 ayat (2) huruf c UUPA untuk hak atas tanah. ${ }^{192}$

Hak milik terhadap tanah tidak akan cukup hanya dengan mengandalkan pengakuan dari pemegang hak milik. Hak milik terhadap tanah harus disertai dengan adanya bukti-bukti penunjang, di antaranya adalah Sertifikat Tanah. Apabila pemilik tanah hanya mengandalkan sejarah turun temurun tanpa adanya sertifikat tanah, maka tanah tersebut dapat dipertanyakan status keabsahannya, sertifikat sendiri menurut pasal 1 angka 20 PP No. 24 Tahun 1997 tentang Pendaftaran Tanah, adalah surat tanda bukti hak yang terkuat sebagaimana dimaksud dalam pasal 19 ayat (2) huruf c UUPA untuk hak atas tanah. ${ }^{193}$ Berdasarkan paparan tersebut, dapat dikatakan bahwa status tanah adat "pauman" di Desa Lebah Sempaga Lombok Barat tidak mempunyai legalitas yang jelas karena belum memiliki sertifikat.

Hak milik terhadap tanah dapat dimiliki oleh perseorangan maupun badan hukum. ${ }^{194}$ Badan hukum yang dapat memiliki hak milik terhadap tanah adalah bank pemerintah (bank negara), koperasi pertanian, badan keagamaan, dan badan sosial. ${ }^{195}$.

Berdasarkan ketentuan Pasal 6 Undang-undang Pokok Agraria bahwa: "Semua hak atas tanah mempunyai fungsi sosial", sehingga hak-hak yang melekat terhadap tanah juga mempunyai fungsi sosial termasuk hak milik.

Artinya, meskipun tanah tersebut sudah mempunyai status sebagai tanah hak milik dari subjek hak (pemegang hak) namun tanah tersebut tidak boleh dipergunakan sematamata hanya untuk kepentingan pribadi saja, tanpa melihat dampak negatif dari pengolahan

${ }^{191}$ Penjelasan Umum Pasal 22 Undang-Undang Pokok Agraria No. 5 Tahun 1960.

${ }^{192}$ Urip Santoso, Hukum Agraria Kajian Komprehensif (Jakarta: Kencana Prenadamedia, 2012), 98.

${ }^{193}$ Santoso, Hukum Agraria, 98.

${ }^{194}$ Pasal 21 ayat (1) Undang-Undang Pokok Agraria Nomor 5 Tahun 1960.

${ }^{195}$ Pasal 1 Peraturan Pemerintah Nomor 38 Tahun 1963 tentang Penunjukan Badan-badan Hukum yang dapat mempunyai Hak Milik atas Tanah. 
tanah tersebut, perilaku seperti ini tidak dibenarkan secara hukum, dikarenakan harus ada keseimbangan antara kepentingan pemerintah dan kepentingan masyarakat.

Dengan demikian, pada dasarnya "tanah pauman” dapat dibuatkan sertifikat dengan cara menjadikan kelompok "pauman" menjadi lembaga adat atau lembaga sosial yang mempunyai badan hukum tetap yang diakui oleh negara.

Berbeda dengan pengaturan hak milik dalam UUPA, hukum adat memandang tanah bukan sekedar kebutuhan primer saja bagi masyarakat adat, tetapi tanah juga dianggap merupakan benda berjiwa yang tidak boleh dipisahkan dengan manusia. Tanah dipahami secara luas meliputi semua unsur bumi, air, udara, kekayaan alam, serta manusia sebagai pusat, maupun roh-roh di alam supranatural yang terjalin secara menyeluruh dan utuh. ${ }^{196}$

Hukum adat memandang hak primer tidak diberikan kepada individu, melainkan masyarakat. ${ }^{197}$ Berdasarkan konsep tersebut, maka tanah ulayat sebagai hak kepunyaan bersama dari suatu masyarakat, hukum adat memandang tanah adalah milik masyarakat adat bersama dan digarap atau dikelola bersama.

Hukum adat beranggapan tanah adalah milik bersama karena berasumsi bahwa tanah sebagai pemberian/anugerah dari suatu kekuatan gaib, bukan dipandang sebagai sesuatu yang diperoleh secara kebetulan atau karena kekuatan daya upaya masyarakat adat tersebut. Mengacu pada pemahaman konsep di atas, berarti sesungguhnya hak atas tanah menurut hukum adat terdiri dari dua bentuk, yaitu hak ulayat (komunal) dan hak individu.

Berdasarkan konsep di atas, masyarakat Dusun Lebah Sempaga memiliki "tanah pauman" secara bersama-sama (komunal) dan memiliki hak atas bangunan rumah secara individu. Oleh karena itu, berdasarkan aturan adat di Dusun Lebah Sempaga, "tanah pauman" yang ditempati oleh warga untuk mendirikan rumah tidak boleh diperjual belikan. b. Kepemilikan Hak Atas Tanah Kosong Menurut Hukum Islam

Membuka dan mengelola tanah kosong dalam hukum Islam disebut ibya' al-mawat. Adapun ibya al-mawat secara terminologis berarti membuka tanah yang tidak bertuan dan belum pernah dikelola untuk dipersiapkan dan dijadikan sebagai tanah yang bermanfaat, untuk perumahan, lahan pertanian, dan lain sebagainya. ${ }^{198}$

\footnotetext{
${ }^{196}$ Harsono, Hukum Agraria, 180.

${ }^{197}$ Harsono, Hukum Agraria, 181.

${ }^{198}$ Sabiq, Fiqih as-Sunnah, 302.
} 
Sulistiorini, B. S., Problematika Eksekusi Putusan Harta Bersama di Atas Tanah Adat

Secara etimologi kata ibya artinya menjadikan sesuatu yang mati menjadi hidup, dan al-Mawat ialah sesuatu yang tidak bernyawa atau tidak berfungsi, dalam konteks ini ialah tanah yang tidak bertuan atau tanah yang belum pernah dimiliki seseorang, maupun yang belum digarap. ${ }^{199}$

Ibya al-Mawat bertujuan agar lahan-lahan yang gersang menjadi tertanami, yang tidak produktif menjadi produktif, maupun untuk bangunan. Sebidang tanah atau lahan dikatakan produktif, apabila menghasilkan atau memberi manfaat kepada masyarakat. ${ }^{200}$ Adapun yang mendasari ibya al-mawat adalah hadis-hadis Rasulullah SAW. Hadis-hadis tersebut sebagai berikut:

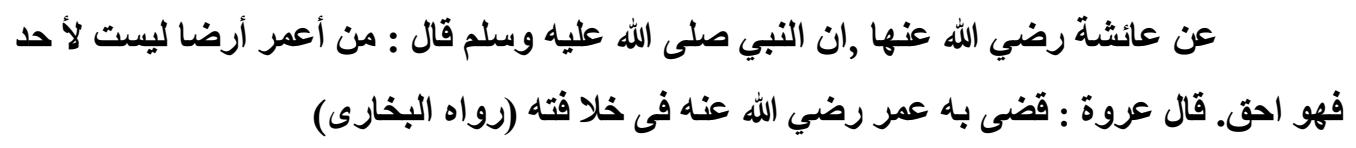

Artinya: Dari Aisyah r.a, Nabi SAW pernah bersabda: "Orang yang mengolah lahan yang tidak dimiliki siapa pun lebih berhak untuk memilikinya". Urwah berkata, Umar r.a memberi keputusan demikian pada masa kekhalifahannya (HR Bukhari). ${ }^{201}$

Dengan adanya hadis tersebut maka ibya al mawat diperbolehkan, apalagi jika seseorang tidak mempunyai pekerjaan dan tidak dapat menafkahi keluarganya maka lebih baik seseorang tersebut mengelola tanah tidak bertuan tersebut. Seruan terhadap ibya almawat atau menghidupkan tanah kosong sangat dianjurkan dalam Islam, karena Islam senantiasa mengajarkan kepada manusia untuk memperluas peradaban, mengeksploitasi kekayaannya, dan mengambil berkahnya sehingga ketika manusia menjadi kaya dapat saling tolong menolong, dan dapat memanfaatkan kekayaan yang terdapat dalam alam semesta, tentu saja dengan catatan membelanjakan semua kekayaannya di jalan Allah. Allah berfirman mengenai seruan tentang Ibya al-Mawat dalam al-Qur'an Surat Muhammad (47): 38 .Artinya: Ingatlah, kamu Ini orang-orang yang diajak untuk menafkahkan (hartamu) pada jalan Allah. Maka di antara kamu ada yang kikir, dan siapa yang kikir sesungguhnya dia hanyalah kikir terhadap dirinya sendiri. Dan Allah-lah yang Maha Kaya sedangkan kamulah orang-orang yang berkehendak (kepada-Nya) dan jika kamu berpaling niscaya dia akan mengganti (kamu) dengan kaum yang lain dan mereka tidak akan seperti kamu ini. ${ }^{202}$

${ }^{199}$ Hendi Suhendi, Fiqh Muamalah (Jakarta: Raja Grafindo Persada, 2010), 265.

${ }^{200}$ Abdullah bin Muhammad Ath-Thayyar, Abdullah bin Muhammad Al-Muthlaq, Muhammad bin Ibrahim Al-Musa, Ensiklopedi Fiqh Muammalah dalam Pandangan 4 Madzhab, terj. Miftahul Khairi (Yogyakarta: Maktabah Al-Hanif, 2014), 403.

${ }^{201}$ Muhammad ibn Isma'il al-Bukhari, Sahih al-Bukhari, Juz III (Beirut: Dar al-Kutub al'Ilmiyyah, 1992), 506.

${ }^{202}$ Kementerian Agama RI, Al-Qur'an, 510.

Copyright (C) 2019 Schemata Journal

Available online at http://journal.uinmataram.ac.id/index.php/schemata 
Sulistiorini, B. S., Problematika Eksekusi Putusan Harta Bersama di Atas Tanah Adat

Dari ayat al-Qur'an di atas dapat disimpulkan bahwa Islam mengajarkan tidak sebanyak-banyak kita mempunyai jumlah harta, namun Islam menekankan kepada kemampuan dalam mengelola dan memanfaatkannya.

Tata cara membuka tanah kosong atau tanah tidak bertuan dalam Islam juga diatur, membuka tanah kosong atau tanah tidak bertuan dilakukan dengan cara mendirikan bangunan atau memberi tanda, menanam pohon, menyuburkan dan lain sebagainya. ${ }^{203}$

Setelah menggarap atau membuka tanah kosong dengan itikad baik, dan untuk mendapatkan kepastian hukum dan kepastian hak, dalam Islam pun diatur mengenai perizinan dari pemerintah, Fuqaha sepakat bahwa ibya al-mawat menjadi sebab kepemilikan dan demi kemaslahatan umum ibya al-mawat memerlukan izin pemerintah, karena pada saat ini kita berada di negara hukum yang semuanya tidak dapat disandarkan atas dasar pengakuan semata, kita memerlukan bukti otentik guna melindungi hak pembuka lahan atau tanah kosong. Dengan adanya izin pemerintah maka urusan umum atau kepentingan umum dapat diatur dengan tertib.

Jadi, berdasarkan ketentuan hukum Islam seharusnya tokoh masyarakat dan tokoh adat Dusun Lebah Sempaga harus berupaya untuk membuatkan sertifikat atas "tanah pauman" agar mempunyai legalitas yang jelas. Pemerintah desa bersama dengan tokoh agama, tokoh masyarakat dan tokoh adat juga perlu membuat aturan tertulis tentang hak dan kewajiban masyarakat yang menempati tanah adat. Hal ini perlu dilakukan untuk menciptakan ketertiban dan kejelasan hukum jika sewaktu-waktu terjadi sengketa.

\section{Status Kepemilikan Bangunan di Atas Tanah Adat di Desa Lebah Sempaga}

Berdasarkan hasil wawancara penulis dengan tokoh masyarakat di Desa Lebah Sempaga, siapapun boleh mendirikan bangunan di atas tanah adat "pauman" dengan syarat mereka adalah penduduk asli Dusun Lebah Sempaga. Walaupun demikian, meskipun berhak untuk membangun rumah, bukan berarti masyarakat mempunyai hak milik atas tanah tersebut. Masyarakat hanya mempunyai hak milik atas bangunan rumah saja, bukan atas tanah tempat mendirikan bangunan rumah tersebut. Oleh karena itu, masyarakat tidak diperbolehkan untuk menjual tanah tempat didirikan rumah tersebut.

Sebagian besar rumah yang dibangun di atas tanah adat "pauman" merupakan rumah permanen yang sulit untuk dibongkar. Oleh karena itu, jika terjadi sengketa terhadap bangunan tersebut tentu akan menimbulkan kesulitan untuk membongkarnya.

${ }^{203} \mathrm{Al}-\mathrm{Musa}$, Ensiklopedi Fiqh, 405.

Copyright $\odot 2019$ Schemata Journal

Available online at http://journal.uinmataram.ac.id/index.php/schemata 
Sulistiorini, B. S., Problematika Eksekusi Putusan Harta Bersama di Atas Tanah Adat

\section{Pertimbangan Hukum Majelis Hakim Pengadilan Agama Giri Menang dalam Memutuskan Gugatan Harta Bersama di Atas Tanah Adat}

Pertimbangan hakim merupakan salah satu aspek terpenting dalam menentukan terwujudnya nilai dari suatu putusan hakim yang mengandung keadilan (ex aequo et bono) dan mengandung kepastian hukum, di samping itu, juga mengandung manfaat bagi para pihak yang bersangkutan sehingga pertimbangan hakim ini harus disikapi dengan teliti, baik, dan cermat. Hakim dalam pemeriksaan suatu perkara juga memerlukan adanya pembuktian, di mana hasil dari pembuktian itu digunakan sebagai bahan pertimbangan dalam memutus perkara. Pembuktian bertujuan untuk memperoleh kepastian bahwa suatu peristiwa/fakta yang diajukan itu benar-benar terjadi, guna mendapatkan putusan hakim yang benar dan adil. Hakim tidak dapat menjatuhkan suatu putusan sebelum nyata baginya bahwa peristiwa/fakta tersebut benar-benar terjadi, yakni dibuktikan kebenaranya, sehingga nampak adanya hubungan hukum antara para pihak. ${ }^{204}$

Berdasarkan hasil wawancara penulis dengan Majelis Hakim, terungkap bahwa Majelis Hakim dalam memberikan putusan terhadap perkara tersebut mempertimbangkan bahwa harta yang diperoleh selama masa perkawinan dan harta yang dihasilkan dari harta perkawinan maupun dari harta pribadi suami maupun istri menjadi harta bersama, bahwa Majelis Hakim berpijak pada kaedah hukum menyatakan "semua harta yang ada dalam rumah tangga merupakan harta bersama, kecuali jika terbukti lain", hal ini ada pada Pasal 35 ayat 1 Undang-Undang Nomor 1 Tahun 1974 tentang Perkawinan juncto Pasal 85 Kompilasi Hukum Islam. Selain itu, majelis juga mempertimbangkan bukti-bukti di persidangan, apakah terbukti harta bersama atau tidak, karena kalau terbukti ya dikabulkan, tetapi kalau tidak ya ditolak. Kalau gugatan itu cacat obscuur libel biasanya tidak dapat diterima. Pertimbangan hukumnya juga mengacu pada alat-alat buktinya seperti alat bukti surat, saksi, dan pengakuan.

Pertimbangan yang digunakan berdasarkan pada pembuktian yaitu berdasarkan keterangan-keterangan dari saksi (alat bukti saksi) dan bukti surat, selain itu hakim mempertimbangkan fakta hukum yang terjadi di persidangan, apakah betul rumah yang dijadikan sengketa dalam gugatan harta bersama tersebut dibangun setelah pernikahan. Majelis hakim juga mempertimbangkan hasil pemeriksaan setempat, menggali keterangan dari tokoh masyarakat dan tokoh adat yang ada di Desa Lebah Sempaga. Informasi yang digali oleh hakim berkaitan dengan status tanah tempat berdirinya rumah yang menjadi

${ }^{204}$ Arto, Praktek Perkara Perdata, 141.

Copyright (C) 2019 Schemata Journal

Available online at http://journal.uinmataram.ac.id/index.php/schemata 
obyek sengketa antara penggugat dengan tergugat. Berdasarkan hasil penelitian penulis di Desa Lebah Sempaga, tanah tempat berdirinya rumah tersebut merupakan tanah adat yang dimiliki secara bersama-sama oleh masyarakat yang dipimpin oleh ketua adat. Adapun tanah adat tersebut dinamakan tanah adat pauman, masyarakat hanya boleh membangun rumah dengan syarat-syarat yang telah ditentukan oleh adat tetapi tanah tersebut tidak boleh dimiliki secara pribadi.

Putusan Pengadilan Agama Giri Menang Nomor: 0287/Pdt.G/2017/PA.GM seperti yang diuraikan dalam amar putusannya, terdapat harta bersama. Mengenai akibat hukum dari perceraian terhadap harta bersama, bahwa setelah adanya perkawinan maka harta kekayaan yang diperoleh baik dari pihak suami atau istri menjadi harta bersama sepanjang tidak ditentukan lain dalam perjanjian perkawinan dan jika perkawinan putus, masing-masing berhak $1 / 2$ (seperdua) dari harta tersebut, karena selama perkawinan terdapat adanya harta bersama maka Hakim disini memberikan putusan mengenai besarnya bagian masing-masing. Pengadilan menetapkan pembagian harta bersama tersebut 1/2 (seperdua) bagian untuk penggugat, dan $1 / 2$ (seperdua) bagian untuk tergugat.

Dari bukti-bukti yang ada maka dasar pertimbangan Majelis Hakim dapat diklasifikasikan menjadi: pertimbangan alat bukti, pertimbangan fakta kejadian dan pertimbangan fakta hukum.

1. Alat Bukti

Alat bukti adalah adanya surat tulisan dan adanya saksi (dari keluarga terdekat dan tokoh masyarakat yang ada di lingkungan tempat tinggal). Adanya alat bukti disini maka semakin memperkuat gugatan atas suatu perkara yang disidangkan. Adapun alat bukti berupa surat yang diajukan oleh Penggugat antara lain:

a. Fotokopi Kartu Tanda Penduduk Kabupaten Lombok Barat Provinsi Nusa

Tenggara Barat atas nama Penggugat yang telah dinazegelen dan telah dicocokkan dengan aslinya yang ternyata sesuai (P.1);

b. Fotokopi Akta Cerai atas nama Penggugat dan Tergugat yang dikeluarkan oleh Panitera Pengadilan Agama Giri Menang yang telah dinazegelen dan telah dicocokkan dengan aslinya yang ternyata sesuai (P.2);

c. Fotokopi Surat Pemberitahuan Pajak Terhutang Pajak Bumi dan Bangunan Tahun 2015 atas tanah seluas $83.300 \mathrm{M}^{2}$ atas nama Pauman Dusun Lebah Sempaga yang dikeluarkan oleh Kepala Dinas Pendapatan dan Pengelolaan Keuangan Daerah Kabupaten Lombok Barat tanggal 03 Maret 2015 dan Surat Setoran Pajak Daerah

\section{Copyright $\odot 2019$ Schemata Journal}

Available online at http://journal.uinmataram.ac.id/index.php/schemata 
Sulistiorini, B. S., Problematika Eksekusi Putusan Harta Bersama di Atas Tanah Adat

(SSPD) tanggal 07 September 2016 yang telah dinazegelen dan telah dicocokkan dengan aslinya yang ternyata sesuai (P.3);

d. Asli hasil cetak (print out) foto rumah dan dapur yang telah dinazegelen (P.4).

2. Fakta Hukum

Fakta hukum adalah fakta atau kejadian dalam sidang betul-betul terjadi dengan disertai landasan hukum. Oleh karena Tergugat tidak hadir dalam persidangan setelah dipanggil secara sah dan patut, maka majelis hakim mempertimbangkan Pasal 149 ayat 1 R.Bg. putusan yang dijatuhkan tanpa hadirnya Tergugat (verstek) dapat dikabulkan sepanjang berdasarkan hukum dan beralasan. Adapun obyek sengketa berupa rumah terbukti sebagai harta bersama Penggugat dan Tergugat sehingga majelis hakim mempertimbangkan Pasal 37 Undang-Undang Nomor 1 Tahun 1974 tentang Perkawinan jo Pasal 97 Kompilasi Hukum Islam. Oleh karena itu, harta tersebut dibagi 1/2 bagian untuk Penggugat dan 1/2 bagian untuk Tergugat. Selain itu ditemukan fakta bahwa tanah tempat berdirinya rumah tersebut merupakan tanah adat dan bukan milik Penggugat dan Tergugat sehingga majelis hakim mempertimbangkan hal tersebut akan menyulitkan saat pelaksanaan eksekusi nantinya, sehingga yang ditetapkan sebagai harta bersama adalah harga nilai jual dari sebuah rumah permanen ukuran $7 \times 6 \mathrm{M}^{2}$ serta dapur ukuran $5 \times 4 \mathrm{M}^{2}$, hal ini sesuai dengan Yurisprudensi Mahkamah Agung RI Nomor 58 K/AG/2015 tanggal 27 Januari 2015, bahwa gugatan harta bersama semacam itu hanya dapat digugat nilainya saja.

3. Fakta Kejadian dalam Persidangan

Fakta kejadian adalah suatu bentuk kesimpulan yang diperoleh seorang hakim berdasarkan atas fakta yang terjadi dalam persidangan dikaitkan dengan alat bukti dan fakta hukum. Fakta kejadian dalam perkara Nomor: 0287/Pdt.G/2017/PA.GM adalah pihak Tergugat meskipun sudah dipanggil secara sah dan patut, namun Tergugat tidak datang di persidangan sehingga majelis hakim memeriksa perkara tersebut secara verstek.

Pertimbangan hukum yang digunakan oleh Majelis Hakim dalam memutuskan perkara gugatan harta bersama di atas tanah adat Nomor: 0287/Pdt.G/2017/PA.GM sudah sesuai peraturan perundang-undangan yang berlaku di Indonesia. Pertimbangan hukum yang digunakan juga melihat realita sosial yang terjadi di Desa Lebah Sempage, Kecamatan Narmada, Kabupaten Lombok Barat. Dengan demikian, putusan yang diambil oleh majelis hakim dapat memberikan rasa keadilan bagi masyarakat.

Secara umum, putusan perkara gugatan harta bersama No. 0287/Pdt.G/2017/PA.GM sudah sesuai dengan hukum dan peraturan perundang- 
undangan yang berlaku, baik dari segi formil ataupun materilnya. Hanya saja, amar putusan dalam perkara tersebut masih kurang lengkap karena tidak mencantumkan harga atau nilai bangunan yang akan dibagi nilainya oleh Penggugat dan Tergugat. Seharusnya, majelis hakim mencantumkan secara jelas harga bangunan tersebut agar tidak timbul kesan bahwa putusan tersebut kabur atau tidak jelas.

Adapun yang berkaitan dengan bagian masing-masing Penggugat dan Tergugat yang tercantum pada diktum ke-4 putusan di atas, yakni mendapat bagian masing-masing 1/2 dari harta bersama tersebut telah sesuai dengan peraturan perundang-undangan yang mengatur tentang harta bersama.

\section{Hambatan Eksekusi Harta Bersama Di Atas Tanah Adat Di Desa Lebah Sempaga Kabupaten Lombok Barat}

Berdasarkan hasil wawancara penulis dengan Majelis Hakim yang menangani perkara gugatan harta bersama di atas tanah adat No. 0287/Pdt.G/2017/PA.GM, ada beberapa kendala di antaranya adalah obyek sengketa berupa rumah. Sebuah rumah ketika ingin dibagi tentu tidak bisa dibagi bangunannya, karena jika bangunannya yang dibagi maka yang didapatkan oleh para pihak hanya berupa bongkaran bangunan rumah yang tidak memiliki manfaat untuk para pihak.

Di samping itu, obyek sengketa berupa bangunan rumah dibangun di atas tanah yang berstatus sebagai tanah adat. Hal ini tentu akan menyulitkan bagi pengadilan dan pihak yang bersengketa untuk membagi rumah tersebut. Sehingga solusi yang ditawarkan oleh majelis hakim adalah membagi nilai atau harga dari rumah tersebut. Secara umum kendala-kendala tersebut memang tidak terlalu berat untuk dijalankan ketika ada orang lain yang mau membeli rumah tersebut dan hasil penjualan rumah dibagi dua oleh Penggugat dan Tergugat.

Kendala-kendala yang dihadapi oleh Penggugat dan Tergugat sebenarnya bisa saja dibantu penyelesaiannya oleh pengadilan agama dengan cara mengajukan eksekusi. Namun pada kenyataanya meskipun perkara tersebut sudah mempunyai kekuatan hukum tetap, akan tetapi Penggugat tidak mengajukan eksekusi sehingga pengadilan agama tidak bisa melakukan tindakan hukum yang tidak pernah diminta oleh penggugat. Jika sekiranya penggugat mengajukan permohonan eksekusi, dalam praktik pengadilan agama dikenal ada dua eksekusi yaitu Eksekusi Riil atau Nyata dan Proses Eksekusi Pembayaran Sejumlah Uang. Jika melihat pada kasus gugatan harta bersama No. 0287/Pdt.G/2017/PA.GM, maka eksekusi dengan pembayaran sejumlah uang sangat tepat untuk diterapkan. Dalam

\section{Copyright $\odot 2019$ Schemata Journal}

Available online at $\mathrm{http}: / /$ journal.uinmataram.ac.id/index.php/schemata 
Sulistiorini, B. S., Problematika Eksekusi Putusan Harta Bersama di Atas Tanah Adat

pelaksanaan lelang untuk eksekusi dalam perkara pembagian harta bersama cenderung terjadi kendala-kendala, baik dalam memeriksa ataupun memutus perkara di Pengadilan Agama. Kendala-kendala tersebut adalah sebagai berikut:

1. Koordinasi antara pengadilan dalam pelaksanaan kejurusitaan.

2. Kesulitan pelaksanaan keputusan. Sering suatu putusan dalam pelaksanaannya mengalami hambatan. Hambatan itu bisa datang dari pengadilan itu sendiri seperti amar putusan yang tidak jelas, pertimbangan yang tidak lengkap, dan amar putusan yang kabur.

3. Kurang profesionalnya pejabat juru sita.

Pada perkara gugatan harta bersama No. 0287/Pdt.G/2017/PA.GM di atas, memang ada beberapa kendala yang ditemukan dalam proses pembagian harta bersama sebagaimana telah disebutkan di atas. Akan tetapi sebagai solusi untuk mengatasi kendala tersebut, Majelis Hakim Pengadilan Agama Giri Menang telah menawarkan agar salah satu pihak membayar bagian pihak yang lain. Artinya, pihak yang ingin menempati rumah tersebut harus membayar bagian yang merupakan hak dari pihak yang tidak menempati rumah.

Menurut penulis, solusi yang ditawarkan oleh majelis hakim tersebut sudah tepat, akan tetapi amar putusan yang dikeluarkan oleh pengadilan agama masih kurang lengkap. Seharusnya dalam amar putusan tersebut dicantumkan nilai bangunan berdasarkan perkiraan harga jual bangunan rumah tersebut. Namun, jika yang dimaksud oleh majelis hakim adalah harga jual bangunan rumah tersebut, maka harus diperkirakan juga berapa nilai jual bangunan rumah di wilayah tersebut.

Dengan demikian, Penggugat dan Tergugat akan mengetahui berapa kisaran dana yang akan diberikan oleh pihak yang menempati rumah kepada pihak yang tidak menempati rumah sebagai ganti rugi. Menurut penulis, jika jalan terakhir untuk membagi rumah tersebut adalah dengan cara dijual, maka penggugat ataupun tergugat menjual rumah tersebut kepada keluarga yang masih ada ikatan terdekat dengan penggugat dan tergugat. Hal ini dilakukan supaya tidak melanggar ketentuan adat tentang pengaturan bangunan rumah, karena dalam ketentuan adat deretan rumah berdasarkan garis keturunan masingmasing anggota masyarakat yang menempati tanah adat.

\section{Copyright $\odot 2019$ Schemata Journal}

Available online at http://journal.uinmataram.ac.id/index.php/schemata 


\section{KESIMPULAN}

Adapun kesimpulan yang ditemukan adalah sebagai berikut:

1. Ketentuan adat tentang penguasaan bangunan di atas tanah adat "pauman" Desa Lebah Sempaga antara lain: a) Masyarakat hanya memiliki hak milik terhadap bangunan rumah dan tidak memiliki hak milik terhadap tanah tempat didirikannya rumah tersebut. b) Masyarakat yang membangun rumah di atas tanah adat tidak diperbolehkan membuat sertifikat atas nama pribadi karena tanah tersebut bukan milik pribadi. c) Masyarakat dilarang memperjual belikan tanah tempat mendirikan rumah tersebut.

2. Berdasarkan putusan perkara No. 0287/Pdt.G/2017/PA.GM majelis hakim menggunakan pertimbangan-pertimbangan, antara lain: a) Pertimbangan alat bukti b) Pertimbangan fakta kejadian. c) Pertimbangan fakta hukum. Adapun landasan hukum yang digunakan adalah Pasal 37 ayat 1 Undang-Undang Nomor 1 Tahun 1974 tentang Perkawinan jo Pasal 97 Kompilasi Hukum Islam, harta tersebut dibagi 1/2 bagian untuk Penggugat dan $1 / 2$ bagian untuk Tergugat dan Yurisprudensi Mahkamah Agung RI Nomor 58 K/AG/2015 tanggal 27 Januari 2015, bahwa gugatan harta bersama semacam itu (harta bersama berupa rumah yang dibangun di atas tanah adat) hanya dapat digugat nilainya saja, sehingga yang dibagi bukan bangunan rumah secara fisik tetapi yang dibagi adalah nilai atau harga jual rumah tersebut.

3. Hambatan yang dihadapi dalam pelaksanaan eksekusi harta bersama di atas tanah adat pada perkara Nomor: 0287/Pdt.G/2017/PA.GM, antara lain: a). Harta bersama tersebut berupa bangunan rumah yang berdiri di atas tanah adat sehingga sulit bagi para pihak untuk membagi rumah tersebut. Oleh karena itu solusi yang ditawarkan oleh Majelis Hakim adalah membagi nilai dari bangunan rumah, yakni rumah tersebut dijual dan hasil penjualannya dibagi dua antara penggugat dengan tergugat. b). Harta bersama yang dibagi berupa nilai bangunan, penggugat kesulitan untuk menjual rumah sengketa karena tidak ada orang yang mau membeli rumah tersebut. Jika pun ada, calon pembeli akan berpikir panjang, calon pembeli merasa enggan untuk membeli obyek sengketa karena yang dibeli hanya bangunan rumah, sedangkan tanah tempat berdirinya rumah tersebut tidak bisa diperjualbelikan karena berstatus sebagai tanah adat. Oleh karena itu solusi yang ditawarkan oleh Majelis Hakim adalah mengajukan eksekusi dengan pembayaran sejumlah uang. Akan tetapi solusi ini sulit untuk dilaksanakan karena penggugat tidak mempunyai dana yang cukup untuk mengajukan permohonan eksekusi ke Pengadilan Agama Giri Menang.

\section{Copyright $\odot 2019$ Schemata Journal}

Available online at http://journal.uinmataram.ac.id/index.php/schemata 
Sulistiorini, B. S., Problematika Eksekusi Putusan Harta Bersama di Atas Tanah Adat

\section{DAFTAR PUSTAKA}

Ali, Z. (2014). Metode Penelitian Hukum. Jakarta: Sinar Grafika, cet. ke-5.

Arto, M. (1996) Praktek Perkara Perdata pada Pengadilan Agama. Yogyakarta: Pustaka Pelajar.

Asshofa, B. (2010) Metode Penelitian Hukum. Jakarta: Rineka Cipta.

Al-Bukhari, Muhammad ibn Isma'il. (1992). Sahih al-Bukhari, Juz III. Beirut: Dar al-Kutub al-'Ilmiyyah.

Harsono, B. (2008). Hukum Agraria Indonesia. Jakarta: Djambatan.

Manan, A. (2008). Aneka Masalah Hukum Perdata Islam di Indonesia. Jakarta: Kencana.

Narbuko, C., \& Ahmad, H. A. (2002). Metodologi Penelitian. Jakarta: Bumi Angkasa.

Rofiq, A. (1997). Hukum Islam di Indonesia. Jakarta: Raja Grafindo Persada.

Sabiq, S. (2011). Fiqib Sunnah, Jilid 3. Beirut: Al-Asriyah.

Santoso, U. (2012). Hukum Agraria Kajian Komprehensif. Jakarta: Kencana Prenadamedia.

Soekanto, S. (1984). Pengantar Penelitian Hukum. Jakarta: Universitas Indonesia Press.

Subagyo, P. J. (1991). Metode Penelitian dalam Teori dan Praktek. Jakarta: PT. Rineka Cipta.

Sugiono. (2015). Metode Penelitian Kuantitatif Kualitatif dan R\&D. Bandung: Alfabeta, cetakan ke-22.

Sunggono, B. (1998). Metodologi Penelitian Hukum. Jakarta: PT. Raja Grafindo Persada.

Suhendi, H. (2010). Fiqh Muamalah. Jakarta: Raja Grafindo Persada.

Ath-Thayyar, Abdullah bin Muhammad, Abdullah bin Muhammad Al-Muthlaq, Muhammad bin Ibrahim Al-Musa. (2014) Ensiklopedi Fiqh Muammalah dalam Pandangan 4 Madzhab, terj. Miftahul Khairi. Yogyakarta: Maktabah Al-Hanif 
